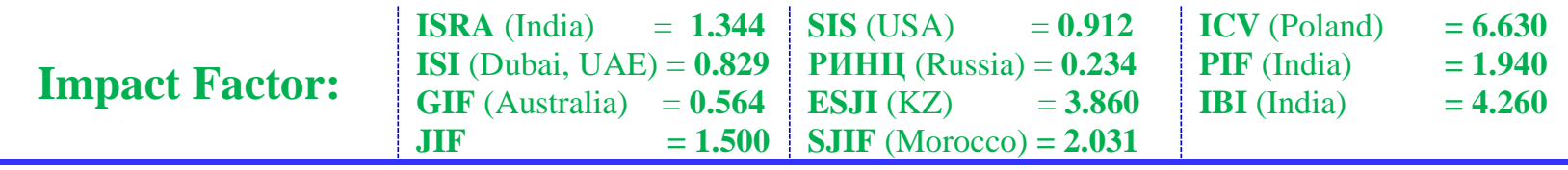

\section{International Scientific Journal Theoretical \& Applied Science}

\author{
p-ISSN: 2308-4944 (print) e-ISSN: 2409-0085 (online) \\ Year: 2017 Issue: 04 Volume: 48
}

Published: $30.04 .2017 \quad \underline{\text { http://T-Science.org }}$

SECTION 25. Technologies of materials for the light and textile industry.

\section{Elena Anatolievna Chalenko}

Associate professor, Ph.D., The Kosygin State University of Russia, ele-ela@yandex.ru

Elena Aleksandrovna Kirsanova Professor, Ph.D., The Kosygin State University of Russia, oimgudt@yandex.ru

Elena Vladimirovna Kazakova Associate professor, The Kosygin State University of Russia, el.kazackova@yandex.ru

\title{
PROBLEMS OF QUALITY MATERIALS FOR SOUND INSULATION IN THE THEATER CURTAIN
}

Abstract: The main reason for the destruction of the materials for curtains of great height are determined. The change of methodology for the evaluation of mechanical properties of materials for curtains are proposed.

Key words: intermission-sliding curtain, material rapport, pattern of the base material, weave cloth, fitting fabric pattern.

Language: English

Citation: Chalenko EA, Kirsanova EA, Kazakova EV (2017) PROBLEMS OF QUALITY MATERIALS FOR SOUND INSULATION IN THE THEATER CURTAIN. ISJ Theoretical \& Applied Science, 04 (48): 211-215.

Soi: http://s-o-i.org/1.1/TAS-04-48-34 Doi: crossef https://dx.doi.org/10.15863/TAS.2017.04.48.34

\section{Introduction}

The red line along which the tableau curtain moves serves as the boundary between the main stage and its front part [1].

The tableau curtain belongs to the category of permanent equipment for the stage. Heavy fabrics of the silk group such as velvet and plush are more often used for the manufacture of curtains. The manufacturing process begins with the preparation and cutting of face and lining cloths. The hem of the curtain is turned over the lining, basted and after premounting of the curtain hanging on the railing (Fig. 1 ) is finally fixed by machine stitching.

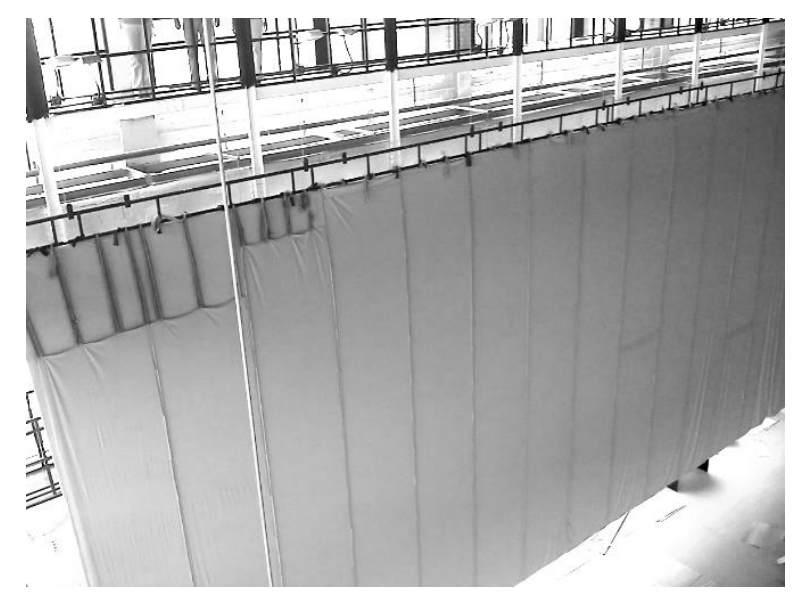

Figure 1 - Photographs of the curtain lining which is fixed to the railing. 


\begin{tabular}{|c|c|c|c|c|c|c|}
\hline Impact Factor: & $\begin{array}{l}\text { ISRA (India) } \\
\text { ISI (Dubai, UAF } \\
\text { GIF (Australia) } \\
\text { JIF }\end{array}$ & $\begin{array}{l}=1.344 \\
=0.829 \\
=0.564 \\
=1.500\end{array}$ & $\begin{array}{l}\text { SIS (USA) } \\
\text { PИНЦ (Russia) } \\
\text { ESJI (KZ) } \\
\text { SJIF (Morocco) }\end{array}$ & $\begin{array}{l}=0.912 \\
=0.234 \\
=3.860 \\
=\mathbf{2 . 0 3 1}\end{array}$ & $\begin{array}{l}\text { ICV (Poland) } \\
\text { PIF (India) } \\
\text { IBI (India) }\end{array}$ & $\begin{array}{l}=6.630 \\
=1.940 \\
=4.260\end{array}$ \\
\hline
\end{tabular}

Acoustic soundproof lining of special velvet is always used in modern tableau curtain [7].

The curtain manufacturing is carried out according to the classic technology, in which the panels before the process of stitching are nailed to the floor of the Studio for alignment $[1,2-4,8]$. starting with joining panels of the main material (Fig. 2 , a), and finishing with the processing of the upper edge (Fig. 2, b) and attaching fringe to the fabric (Fig. 2, c). These methods of processing do not allow to obtain good quality finished product, are very time-consuming and, in addition, do not give even load distribution.

\section{Application area}

The study of the methods of processing historical curtain showed that almost all the processes of its manufacture were made by hand,

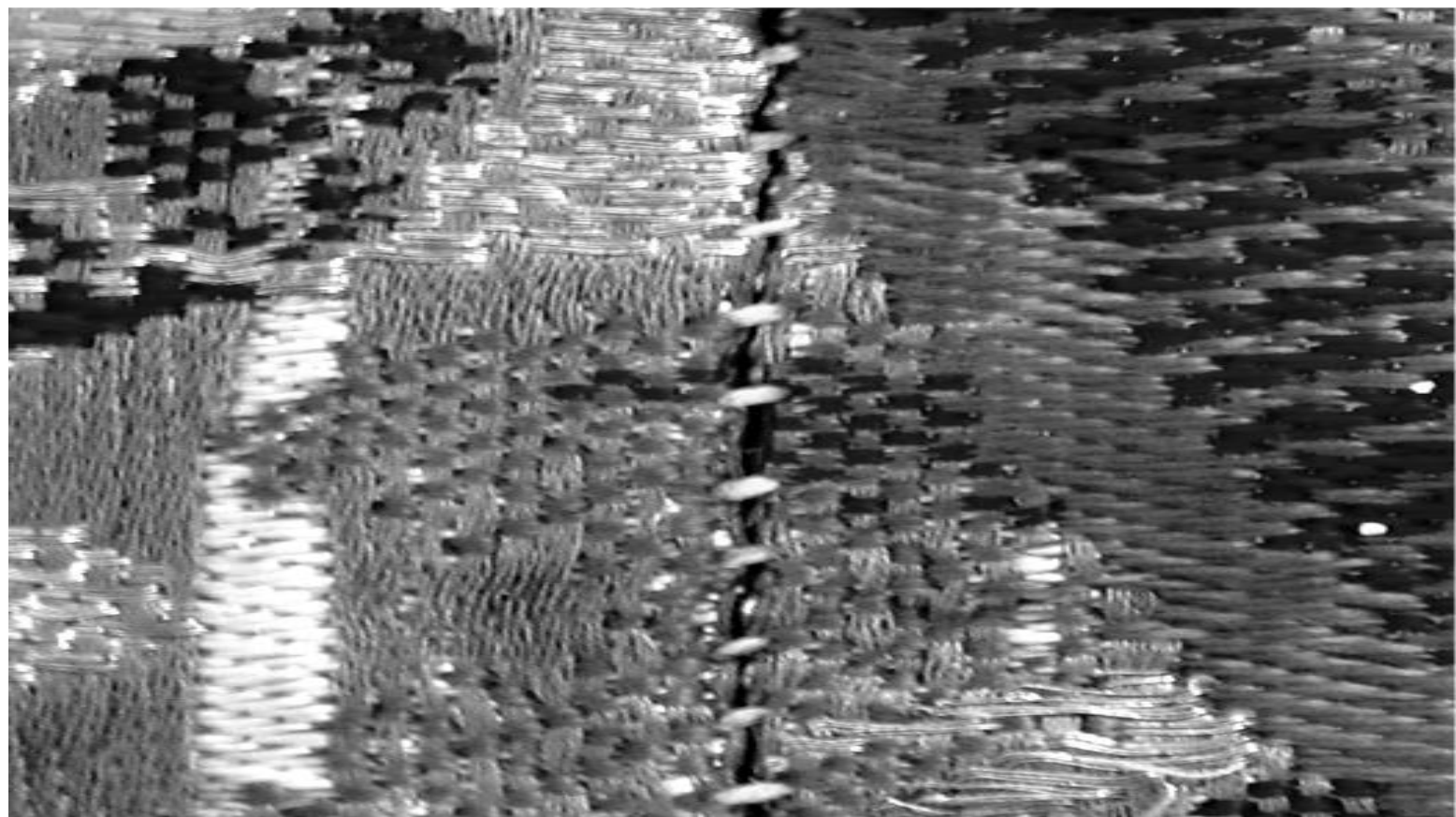

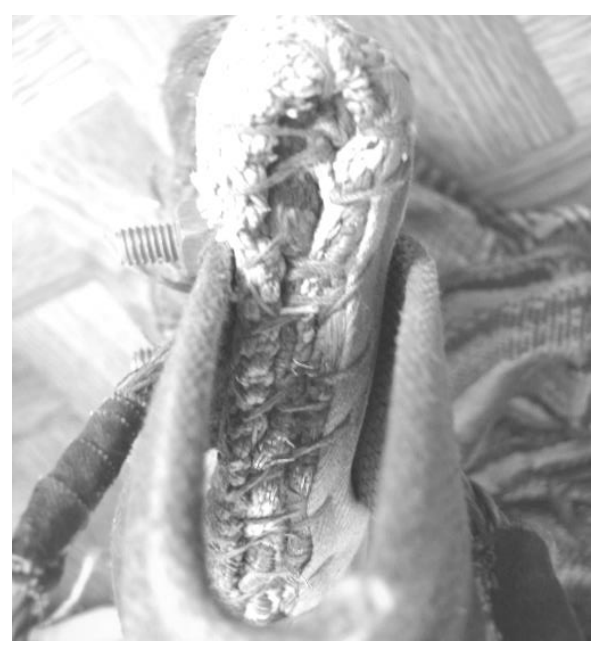

b)

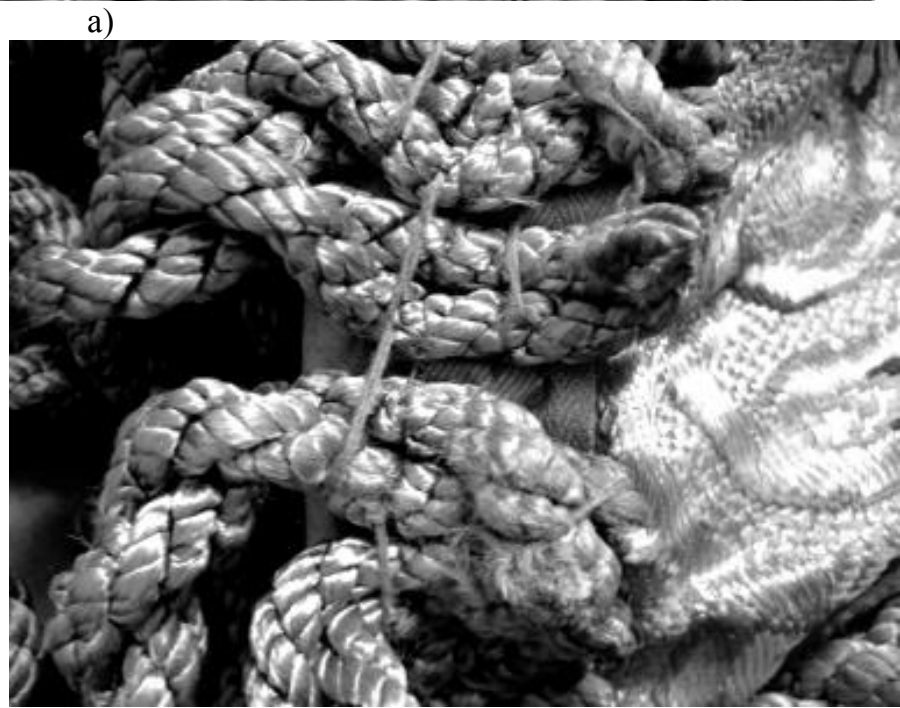

c)

Figure 2 - Photographs. Methods of processing the Bolshoi theatre historic curtain.

ISPC Industry and technology, 


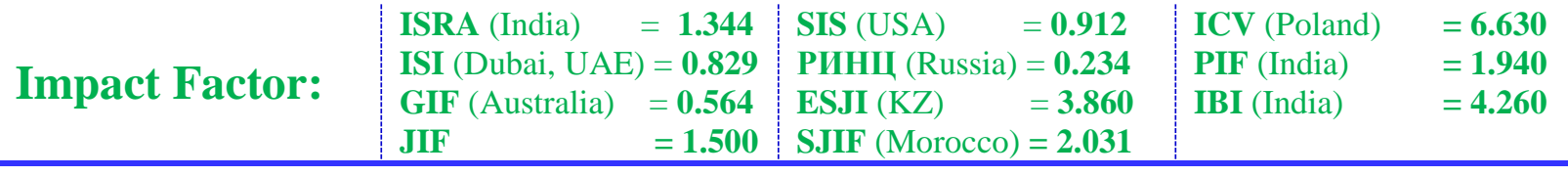

\section{Materials}

During the reconstruction of the Bolshoi theatre of the Russian Federation much attention was paid to the properties of the materials used. Fabric, finishing and binding materials were fireproof and made of modern fibers. During the work on the "stage dressing" the aim was not to restore, but to recreate. This work was performed in such a way that the created object was similar to the original, but changes were made in the symbolics of the material pattern taking into account the historical realities. Modern methods of manufacture which helped improve quality and significantly reduce the time of work were used [2-4].

Considering the parameters of technical specifications for reconstructing the curtains special equipment and components were chosen (table. 1).

Table 1

Characteristics of materials used in the restoration of the Bolshoi theatre curtain.

\begin{tabular}{|l|c|}
\hline \multicolumn{1}{|c|}{ Material name } & Raw material composition \\
\hline Face cloth & $\begin{array}{c}\text { Polyester Trevira CS, } \\
\text { Metallic thread } \\
\text { Thread 100\% Polyester }\end{array}$ \\
\hline Lining cloth & 100\% Polyester \\
\hline Technical fabric & $\begin{array}{c}\text { Polyester Trevira CS, } \\
\text { Canvas (tarpaulin) }\end{array}$ \\
\hline $\begin{array}{l}\text { Haberdashery } \\
\text { agramantika }\end{array}$ & Viscose \\
\hline Technical tape, slings & Cotton, polyester, polyamide, polyester, capron \\
\hline Sewing thread & Cotton, polyester \\
\hline Accessories & Non-ferrous metal, steel \\
\hline Fasteners & Metal \\
\hline Cord for hanging & Capron, polyester \\
\hline
\end{tabular}

\section{Methods.}

Substantial research has been done to determine the methods of predicting fabric mechanical properties.

Materials research has been conducted on the resistance to abrasive influences and mechanical loads.

\section{Results and Discussion}

We conducted research on different materials for abrasion and tensile strength. Technical fabric made of fibre "trevira" and aramid fabric showed the best results of durability. They also have low weight and thickness and are made of flame-retardant fibers (similar to Kevlar), which significantly reduced the thickness of the package materials during processing of the hem and top of the curtains.

The calculated value of breaking length of 830 $\mathrm{m}$, which should ensure its operational reliability, was determined for stage velvet Amadee WP. When determining the breaking strength of samples of velvet it was found that by reducing the speed of lowering the lower clamp, the value of the breaking strength decreases, and, consequently, there is static stretching of the material. The relative deformation of the sample is less than $10 \%$, and conventionally these materials are low-plasticity. The destruction of the material is carried out under conditions of static stretching, in which only potential energy effects the material. The maximum height of the curtain, when the destruction of the material will take place is determined for the selected material. It is $5.83 \mathrm{~m}$.

We decided to join the panels of the main and lining materials on the modern stitching equipment for handling medium and heavy materials (Fig. 3). However, the mass of the joined panels was about $11.9 \mathrm{~kg}$ for linings and 25.8 per $\mathrm{kg}$ for panels of the main fabric. Therefore, the joining of only two panels leads to the formation of an object with mass from 23.8 to $51.6 \mathrm{~kg}$ and width from $2.8 \mathrm{~m}$ to $3.1 \mathrm{~m}$. Handling such heavy objects on the sewing equipment was a serious problem, and in the manufacture of curtains of different types, it was necessary to join from 3 to 17 panels. Thus, we decided not to move the material relative to the sewing equipment, but the equipment relative to the joined pieces of material. For these purposes a special wadding-sewing complex, consisting of a table having $20 \mathrm{~m}$ length and a mobile trolley for sewing machines and the operator, which moves on rails along the table was designed. 


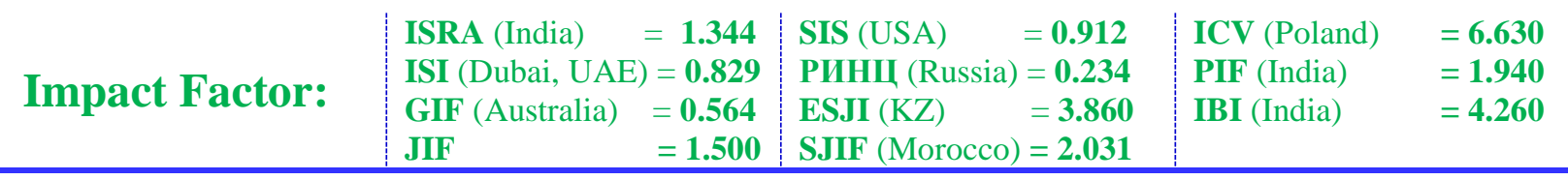

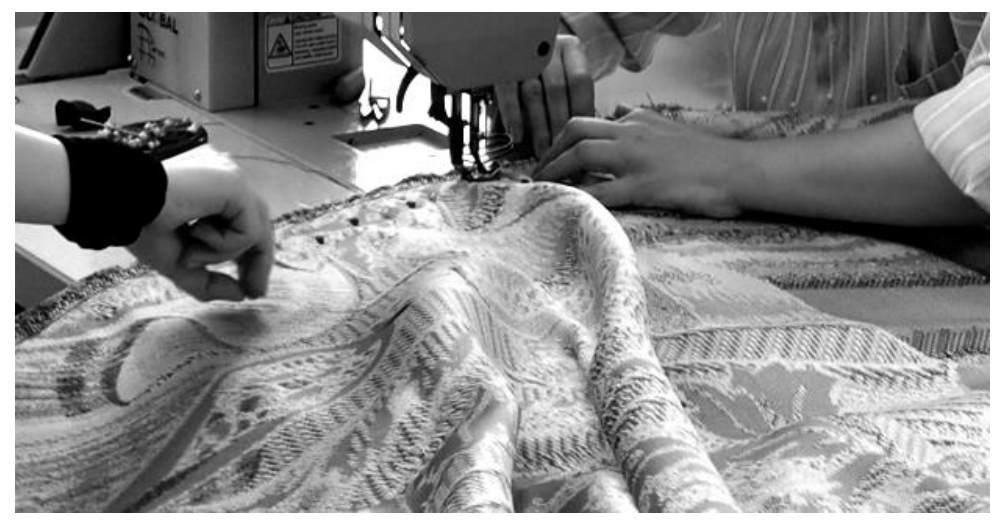

Figure 3 - The use of modern sewing equipment for joining curtain panels

Allowances of the joined panels were pressed open to reduce their thickness, but it was necessary to use household ironing equipment because the industrial equipment for wet-heat processing includes stationary steam generators and are not designed for processing objects with such length. Pressing work had to be done on the floor because of the large mass of the processed cloths (Fig. 4).

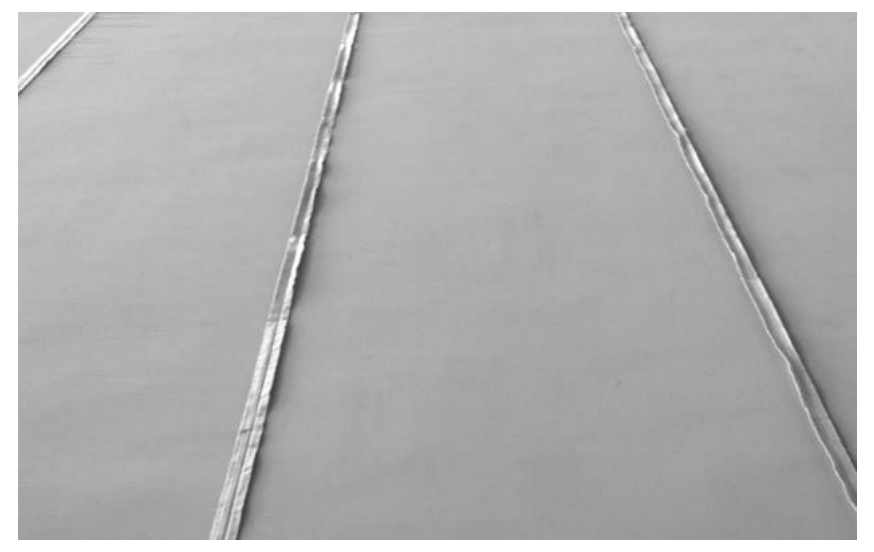

Figure 4 - Pressing open allowances of the joined curtain panels

During the usage of curtain the destruction of the upper part of the lining made of acoustic velvet takes place. It happens during attaching when the binding is stitched to the upper zone or when holes are cut in tarpaulin, reinforced by leather pads for attaching the curtain to the rings and the carriages of the railing, and the distances between the rings are determined by the technological capabilities of the railing on which the curtain moves.

\section{Conclusions}

In the development of the curtains processing technology, it was necessary to select the method of processing: manual or with the use of modern equipment. The fundamental choice was made in favor of the modern sewing equipment use, because machine stitches possess high strength characteristics. In addition, the quality of panel joining with the use of sewing machines is better than in manual joining. Moreover, in the manual method there are 15-16 stitches on each $10 \mathrm{~cm}$ line, while the line of machine stitching has 29-35 stitches on each $10 \mathrm{~cm}$ line have depending on the desired adjustments and the length of each stitch is exactly the same giving more uniform load distribution. This can not be achieved by manual method. The use of sewing equipment to handle such products with large area, high mass and thickness was impossible50 
years ago, but today, in the 21 st century, modern technologies allow qualitatively to join materials of different density and thickness.

However, to prevent the destruction of the curtain, it is advisable to use the index of length breaking, the minimum length at which the sample mass is equal to the breaking load i.e. the conditional length at which the material is destructed under its own weight $[6,9,10]$.

The "Golden" front tableau curtains of the Bolshoi theatre, the working height of which is 12.5 $m$ can be given as an example. The height of the curtain is $13 \mathrm{~m}$. Thus, from the above calculations one can see that the operational reliability of the curtain does not meet the requirements and after four years of usage the destruction of its insulating layer takes place.

Thus, when manufacturing curtains it is necessary to take into consideration the change of materials properties under static tension and find necessary engineering and technological solutions.

\section{References:}

1. Bazanov V (1976) Technique and technology of stage. Moscow: Iskusstvo.

2. Chizhova NV, Chalenko EA (2013) Recreating sets of scene's clothes the Bolshoi Theatre // Global Science and Innovation [Text]: materials of the I International Scientific Conference, Vol. II, ISBN 978-0-9895852-1-7, Chicago, December 17-18th, 2013 / publishing office Accent Graphics communications - Chicago USA, 2013 - p. 419-423.

3. Chizhova NV, Chalenko EA (2013) Wiederherstellung schiebevorhang-pause Bolschoi-Theater // European Science and Technology [Text]: materials of the VI international research and practice conference, Vol. II, ISBN 978-3-941352-31-5, Munich, December 27th - 28th, 2013 / publishing office Vela Verlag Waldkraiburg - Munich Germany, 2013 - p. 247-252.

4. Chizhova NV, Chalenko EA (2014) Features of technological works during reconstruction of the intermission-sliding curtain of a scene of the Bolshoi Theatre // IV Science, Technology and Higher Education [Text]: materials of the IV international research and practice conference, ISBN 978-1-77192-050-6, Westwood, Canada, January 30, 2014/ Westwood, Canada, 2014 p. 340-346

5. Chizhova NV, Chalenko EA, Galkin AV (2014) Opyt provedeniya uchebnoy praktiki studentov pri vossozdanii antraktno-razdvijnogo zanavesa sceny bolshogo teatra// V sbornike: Sbornik nauchnyh statey "Pamyati V. A. Fukina posvyaschaetsy", part 3, ISBN 978-5-87055191-3, ISBN 978-5-87055-192-0, Scientific publication, Moscow: MSUDT, - p. 154-158.

6. Buzov BA, Alymenkova ND (2010) Materialovedenie v proizvodstve izdeliy legkoy promyshlennosti (shveynoe proizvodstvo). ISBN 5-7695-1345-4, Moscow: Akademiya. $448 \mathrm{p}$.

7. Belgorodsky VS, Kirsanova EA, Zhikharev AP (2010) Innovacii $v$ industrii mody/ Uchebnoe posobie/ Moscow: MSUDT, - p. 113.

8. Chalenko EA (2017) Vliyanie tehnologicheskoy obrabotki na svoystva materialov dlya izgotovleniya shveynih izdeliy. V sbornike: Rezulytaty sovremennih nauchnih issledovaniy I razrabotok. Sbornik statey pobediteley II Mejdunarodnoy nauchno-prakticheskoy konferencii. - p. 61-63.

9. Demskaya AA, Kirsanova EA, Vershinina AV, Chalenko EA (2016) Vliyanie svoystv materialov I metodov tehnologicheskoy obrabotki na formirovanie esteticheskogo vospriyatiya shveynih izdeliy. Design and technology. 2016. № 53 (95). p. 51-56.

10. Kirsanova EA, Chalenko EA (2016) Modelirovanie svoystv materialov legkoy promyshlennosty $\mathrm{v}$ zavisimosty ot formy izdekiy. V sbornike: Aktualynye napravleniya fundamentalynyh I prikladnyh issledovaniy. Materialy VIII mejdunarodnoy nauchnoprakticheskoy konferencii.. p. 62-65. 